\title{
İklim Analizine Yönelik Bir Uygulama: Boyabat İlçesi Örneği
}

\section{An Application For Climate Analysis: Case of Boyabat District}

\author{
Prof. Dr. Duran AYDINÖZÜ (iD) 1, Dr. Ufuk SÖZCÜiD2
}

\begin{abstract}
$\ddot{O} \mathbf{z}$
Herhangi bir yerin iklim özelliklerini tespit etmek o yörede yapılacak her türlü ekonomik faaliyetleri planlamada önemli bir yere sahiptir. Bu çalışmada $41^{\circ} 28^{\prime}$ kuzey paraleli ile $34^{\circ} 46^{\prime}$ doğu meridyeninin kesişme noktasında bulunan Boyabat ilçesinin iklim özellikleri ayrıntılı bir şekilde ele alınmıştır. Bu çalışmanın ele alınmasındaki temel neden bu yöreye ait daha önce iklimle ilgili detaylı bir araştırmanın yapılmamış olmasıdır. Bu nedenle araştırmanın amacı öncelikle Boyabat ilçesinin iklim tipini belirlemek ve klimatik özelliklerini ortaya koymak, doğal çevre-insan etkileşimi bağlamında ekonomik faaliyetlere dair planlamalara katkı sağlayabilmektir. Boyabat ilçesinin iklim özelliklerini ortaya koyabilmek için; Meteoroloji Genel Müdürlüğü’nün 1975-2015 arasında Boyabat meteoroloji istasyonuna ait verileri kullanılmıştır. Yörenin iklim tipini belirleyebilmek için, Thornthwaite, De Martonne ve Erinç indislerinden yararlanılmıştır. Boyabat Thornthwaite yöntemine göre yarı kurak, ikinci dereceden mezotermal, su fazlası olmayan yahut pek az olan ve deniz tesirli iklim tipine; De Martonne yöntemine göre step- nemli iklim tipine; Erinç yöntemine göre yarı kurak iklim tipine sahiptir. Bu üç yöntemin ortaya çıkardığı ortak sonuca göre genel anlamda Boyabat kışları serin, yazları sıcak geçen ve az yağış alan bir iklim özelliğine sahiptir. Bu sonuçlar 1şığında yöredeki sosyo-ekonomik faaliyetlere ilişkin öneriler getirilmiştir.
\end{abstract}

Anahtar Kelimeler: İklim, indisler, Boyabat

Makale Türü: Araştırma

\begin{abstract}
Determining the climate characteristics of any place has an important place in planning all kinds of economic activities in that region. In this study, the climatic features of Boyabat district, which is located at the intersection of $41^{\circ} 28$ 'northern parallel and $34^{\circ} 46^{\prime}$ east meridian, are discussed in detail. The main reason for addressing this study is that a detailed study of this region has not been done before. For this reason, the purpose of the research is to determine the climate type of Boyabat district and to reveal its climatic features, to contribute to the plans for economic activities in the context of natural environmenthuman interaction. To reveal the climatic features of Boyabat district; The data of the meteorology station of Boyabat the General Directorate of Meteorology between 1975-2015 was used. In order to determine the climate type of the region, Thornthwaite, De Martonne, Erinç and indices were used. According to the Boyabat Thornthwaite method, it is a semi-arid, second degree mesothermal, low or no water and sea effect climate type; According to De Martonne method, the type of humid climate; According to Erinç method, semi-arid climate type. According to the common result of these three methods, Boyabat has a climate feature that is cool in the winter, hot in the summer and receiving little rainfall. In the light of these results, suggestions have been made regarding socio-economic activities in the region.
\end{abstract}

Keywords: Climate, indices, Boyabat

Paper Type: Research

\footnotetext{
${ }^{1}$ Kastamonu Üniversitesi, Eğitim Fakültesi, daydinozu@ kastamonu.edu.tr.

${ }^{2}$ MEB, Kastamonu Fen Lisesi, usozcu@ hotmail.com.
} 


\section{Giriş}

Herhangi bir yerde, hava olaylarının iklim elemanları bakımından yıl boyunca gösterdiği değişiklikler, o yerin iklimi diye tanımlanır. Uzun süreli atmosfer koşullarının, meteorolojik gözlem ve ölçmeler sonucu elde edilen sayısal verilere dayanılarak açıklanmasına da iklim özellikleri denilmektedir. Yeryüzünde meydana gelen doğal ve beşeri olayların oluşmasında doğrudan veya dolaylı olarak iklimin etkisi bulunmaktadır. Nüfusun dağılışından tarım, ticaret, sanayi, turizm gibi ekonomik faaliyetlere; bitki ve toprak türlerinin dağılışından insanların giyinme, beslenme ve barınma faaliyetlerine kadar pek çok alanda iklimin etkisini görmek mümkündür. Bu yüzden bir yerin iklim özelliklerini tespit etmek önemli bir konudur.

İklim tasniflerinin amacı dünyadaki farklı iklim tiplerini belirlemek, benzer ve farklı mekânların sınırlarını çizmektir. Ancak iklim tiplerinin sayısı, kullanılan haritanın ölçeğine göre değişiklik gösterir. Büyük ölçekli haritalarda yükselti, bakı, orografi, denize olan mesafe gibi faktörlere bağlı çeşitli iklim tipleri ortaya çıkar. Küçük ölçekli haritalarda bu detaylar görülemediğinden daha sade ve daha az iklim çeşidi ile yeryüzündeki iklimlerin sınırları belirlenir. İklimin insan hayatı üzerindeki nüfus, yerleşme, tarımsal faaliyetler, ulaşım ve planlama gibi birçok konu üzerindeki dominant etkisinden dolayı iklim tiplerini ve sınırlarını belirlemek önemlidir (Yılmaz ve Yılmaz, 2013, s. 416). Araştırma sahası Karadeniz Bölgesi'nde yer almasına rağmen belirgin Karadeniz ikliminin özelliklerini taşımayıp, daha çok karasal iklim özelliklerini taşır. Bu nedenle Boyabat ve çevresinin iklim özellikleri detaylı bir şekilde ortaya konulmaya çalışılmıştır.

\section{Araştırma Sahasının Yeri ve Genel Fiziki Özellikleri}

İnceleme alanımız, Karadeniz Bölgesi'nin Batı Karadeniz Bölümü’nde yer alan Sinop İline bağlı bir ilçedir. Boyabat $41^{\circ} 28^{\prime}$ kuzey paraleli ile $34^{\circ} 46^{\prime}$ doğu meridyeninin kesişme noktasında bulunmaktadır. İnceleme sahasının kuzeyini Sinop ili ve Erfelek ilçesi, kuzeybatısını Ayancık, kuzeydoğusunu Gerze, doğusunu Durağan ve Saraydüzü ilçeleri, batısını ise Kastamonu ili çevrelemektedir. Ayrıca ilçe Kastamonu'dan Samsun'a, Sinop’tan Orta Anadolu'ya giden karayolu üzerindedir (Şekil 1).

Araştırma sahası arazileri Mesozoikten ve Kuaternere kadar oluşan farklı yaş grubundaki arazilerden oluşmaktadır. Boyabat havzasında Mesozoik ve Senozoik yaşlı araziler gözlenirken, Gökırmak ile Kolaz Çayı boyunca Kuaterner arazisi de bulunmaktadır. Ayrıca Küre ve Ilgaz dağ sıralarını birbirinden ayıran ovalar Kuaterner döneme ait alüvyonlarla kaplı verimli ovalardır. İlçenin kuzeyini Küre dağları, güneyini ise Ilgaz dağlarının doğu uzantıları sınırlamaktadır. İlçe arazisinde merkezden güneye doğru devamlı bir yükselme görülür. İlçe güney ve doğudan Ilgaz Dağları ile çevrilidir. Ayrıca Sakız ve Aydın Dağı da yörede bulunan diğer dağlık alanlardır.

İlçe arazisini kat eden en önemli akarsu Kızılırmak'ın en büyük kollarından olan Gökırmak'tır. Gökırmak ilçe sınırları içerisinde kabaca güneydoğu doğrultusunda akmakta ve Durağan'ın doğusunda Kızılırmak'a katılarak Karadeniz'e dökülmektedir. İlçenin diğer akarsuları Gazidere Çayı, Çarşak Çayı, Asarcık Çayı ve Çorman Çayıdır. İlçede Gökırmak vadisi boyunca oluşan ve kuzeybatı-güneydoğu doğrultusunda birbiri ardına uzanan, Arım, Gazidere, Asarcık isimli küçük akarsu boyu ovalarının birleşmesiyle Boyabat Ovası oluşturmuştur (Aydınözü, İbret ve İmat, 2012). Küre ve Ilgaz dağ sıralarını birbirinden ayıran ovanın ortalama rakımı 300-450 metredir. Bu ovalar Kuaterner döneme ait alüvyonlarla kaplı verimli ovalardır. 
Şekil 1. İnceleme sahasının lokasyon haritası

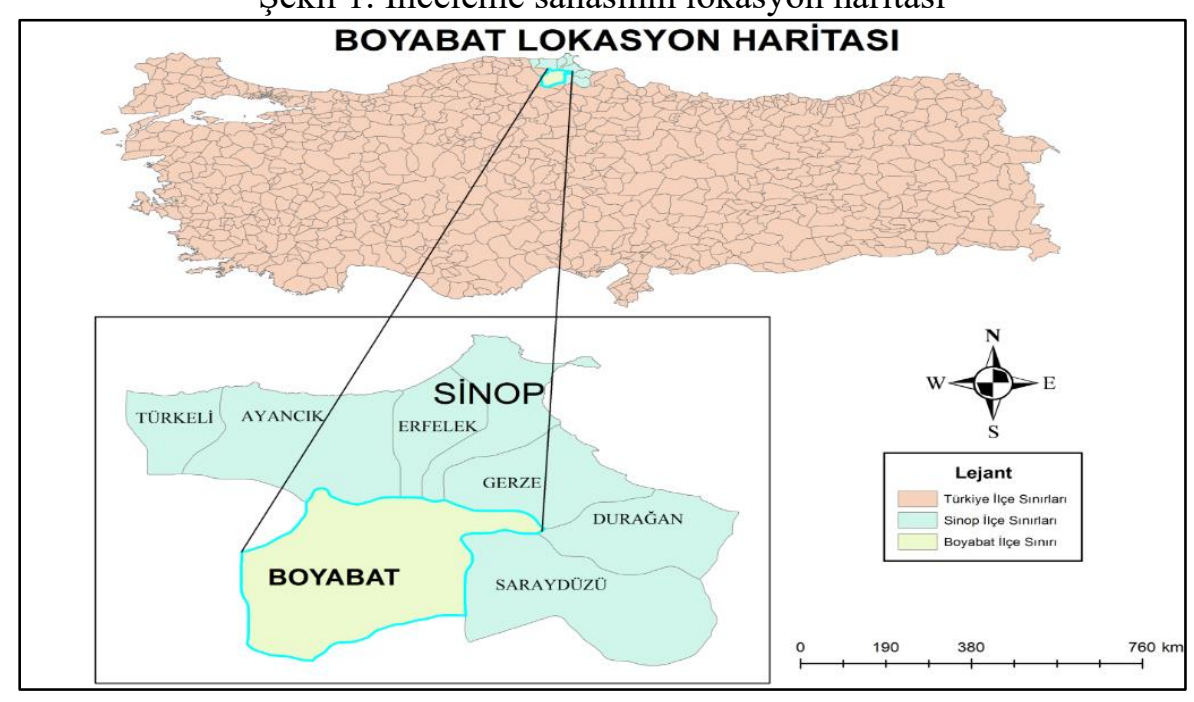

\subsection{Araştırmanın Amacı}

$\mathrm{Bu}$ çalışmada Boyabat ilçesinin iklim özellikleri ayrıntılı bir şekilde ele alınmıştır. Her ne kadar saha ile ilgili çalışmalar yapılmışsa da bu çalışmayla iklim özellikleri daha detaylı irdelenmeye çalışılmıştır. Bu nedenle araştırmanın amacı Boyabat ilçesinin iklim tipini belirlemek ve klimatik özelliklerini ortaya koymak, doğal çevre-insan etkileşimi bağlamında ekonomik faaliyetlere dair planlamalara katkı sağlayabilmektir. Ayrıca bu çalışmanın yapılacak diğer alan çalışmaları için kaynak oluşturacağı düşünülmektedir.

\section{Yöntem}

Boyabat ilçesinin iklim özelliklerini ortaya koyabilmek için; Meteoroloji Genel Müdürlügü̈nün 1975-2015 yılları arasındaki Boyabat meteoroloji istasyonuna ait veriler kullanılmıştır. Ayrıca komşu şehirler olan Sinop ve Kastamonu'ya ait meteoroloji bültenleri elde edilerek ilçenin iklim özellikleri ile kıyaslama yapma imkanı sağlanmıştır. Bu maksatla inceleme sahasındaki meteoroloji istasyonlarına, yağışların buharlaşma ve terleme ile olan ilişkilerinin ortaya konulması için Thornthwaite metodu, yağışlarla sıcaklık arasındaki ilişkilerin ortaya konulması içinde, De Martonne formülü ile Erinç'in yağış etkinlilik indisi uygulanmıştır.

Thorntwaite formülü tatbik edilerek elde edilen su bilançosu tablosu ile inceleme sahasındaki istasyonda yaz ve yaz etrafındaki aylarda evapotranspirasyonun yağış değerinden yüksek, kış ve kışa yakın aylarda ise evapotranspirasyonun yağışlardan düşük olduğu görülür. Bu istasyonda karasallığın etkisiyle biraz daha fazla hissedilen yaz kuraklı̆ğ, kış ve ilkbahar mevsimlerindeki yağış fazlalığının toprakta depo edilmesi ile toprakta biriken suyun kullanılması sayesinde kısalmış olur. O halde bu yerin iklimi kuraktır. Thornthwaite iklim tasnifi bu iki ekstrem arasinda oynar (MGM, 2019).

De Martonne iklim sınıflandırmasında diğer parametrelerin yanında sıcaklık ve yağış da dikkate alınmıştır. Yıllık ortalama yağış ve sıcaklığın yanında, temmuz ve ocak ayı sıcaklık ve yağış ortalamaları arasındaki ilişki hesaplamada göz önünde tutulmaktadır. Yıllık yağış miktarı nemli ve kurak iklimleri ayırmaya imkân verir. Kurak devrelerin tespitinde aylık yağışların yanında buharlaşma da önemli bir parametredir (DMİ, 1972; Akt. MGM, 2019).

De Martonne'nin, yağış miktarlarının doğrudan ortalama sıcaklıklara oranlanması ile elde ettiği indis, karasal bölgelerde gerçekte olduğundan daha nemli bir durumun ortaya çıkmasına sebep olmaktadır. Bu nedenle Erinç, indisin hesaplanmasında ortalama sıcaklık yerine ortalama maksimum sıcaklığı almıştır. Ancak bu değerlendirmede ortalama maksimum sıcaklığın $0^{\circ} \mathrm{C}$ 'nin altına düştüğü aylar, evapotranspirasyonun olmadığı varsayılarak dikkate alınmaz (MGM, 2019). 


\section{Bulgular}

Bu bölümde öncelikle Boyabat ilçesinin sıcaklık, rüzgar, nem ve yăğş özelliklerine ait bulgulara yer verilmiştir. Daha sonra bu bulgulardan yararlanılarak ilçenin Thornthwaite, De Martonne ve Erinç yöntemlerine göre iklim tipi belirlenmiştir.

\subsection{Sıcaklık Özellikleri}

Araştırma sahasının sıcaklık değerlerine ait 32 yıllık rasat sonuçları Şekil 2'de gösterilmiştir.

Şekil 2. Boyabat'ın aylık ortalama, en düşük ve en yüksek sıcaklıklarının dağılışı

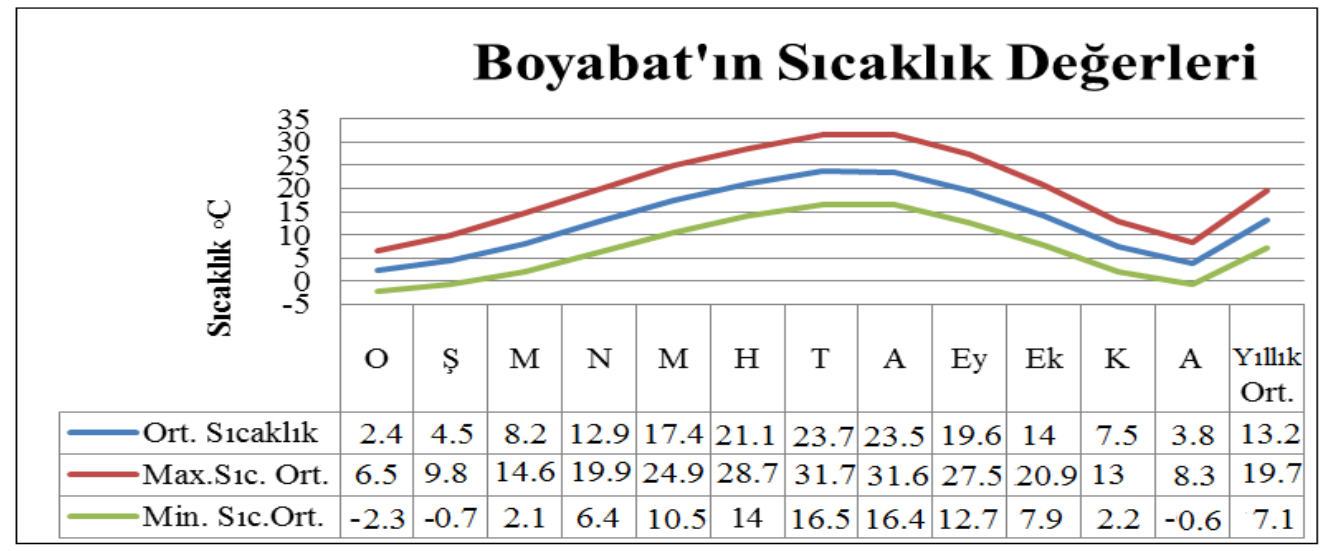

Şekil 2'deki bilgiler incelendiğinde Boyabat' ’n yıllık ortalama sicaklık değerinin $13,2^{\circ} \mathrm{C}$ olduğu görülmektedir. Yıllık ortalama sıcaklığın yüksek olması yükseltinin az $(350 \mathrm{~m})$, deniz etkisinin Gökırmak boyunca buralara kadar ulaşmasıyla ilgilidir. Kış sıcaklık ortalamas $13,6{ }^{\circ} \mathrm{C}$, yaz sicaklık ortalamas $22,8^{\circ} \mathrm{C}$ 'dir. En sicak ay ile en soğuk ay arasında $21,3^{\circ} \mathrm{C}$ fark vardır. Maksimum sıcaklık ortalamaları yazın en yüksek $31,7^{\circ} \mathrm{C}$ 'ye yükselirken, kışın $6,5^{\circ} \mathrm{C}$ olmaktadır. Minimum sicaklık ortalamaları temmuz ayında $16,5^{\circ} \mathrm{C}$, ocak ayında $-2,3^{\circ} \mathrm{C}$ 'dir.

Tablo 1. İnceleme bölgesindeki istasyonların aylık ve yıllık ortalama sıcaklık dağılışı

\begin{tabular}{|c|c|c|c|c|c|c|c|c|c|c|c|c|c|}
\hline & Ocak & Şubat & Mart & Nisan & Mayıs & Haziran & Temmuz & Ağustos & Eylül & Ekim & Kasım & Aralık & $\begin{array}{l}\text { Yillık } \\
\text { Ortalama }\end{array}$ \\
\hline Kast: & -0.7 & 0.7 & 4.4 & 9.6 & 14.0 & 17.6 & 20.5 & 20.1 & 15.7 & 10.5 & 4.7 & 0.7 & 9.8 \\
\hline Sinop & 7.0 & 6.4 & 7.6 & 10.8 & 15.1 & 20.0 & 23.0 & 23.4 & 20.0 & 16.1 & 12.1 & 9.0 & 14.2 \\
\hline
\end{tabular}

Kıyaslama amacıyla incelediğimiz Sinop ve Kastamonu illerine ait ortalama sıcaklık değerleri ise şu şekildedir. Boyabat'ın ortalama sıcaklığ $13.2^{\circ} \mathrm{C}$ iken Kastamonu'nun $9.8^{\circ} \mathrm{C}$, Sinop'un $14,2^{\circ} \mathrm{C}$ 'dir. Kastamonu'da kış sıcaklık ortalamas $10,2^{\circ} \mathrm{C}$ iken Sinop'ta $7,4^{\circ} \mathrm{C}$ 'dir. Yörede görülen en düşük sıcaklık $-16,5^{\circ} \mathrm{C}$ ile 1976 yılı Ocak ayında, en yüksek sıcaklık $45,4^{\circ} \mathrm{C}$ ile 2000 yılı temmuz ayında ölçülmüştür. Tablo 2 ise aylık ve yıllık ortalama donlu gün sayılarını göstermektedir.

Tablo 2. İnceleme bölgesindeki istasyonların aylık ve yıllık ortalama donlu gün sayıları

\begin{tabular}{cccccccccccccccc}
\hline $\begin{array}{c}\text { ISTASYON } \\
\text { ADI }\end{array}$ & $\begin{array}{c}\text { RASAT } \\
\text { YILI }\end{array}$ & $\mathrm{O}$ & $\mathrm{S}$ & $\mathrm{M}$ & $\mathrm{N}$ & $\mathrm{M}$ & $\mathrm{H}$ & $\mathrm{T}$ & $\mathrm{A}$ & $\mathrm{E}$ & $\mathrm{Ek}$ & $\mathrm{K}$ & $\mathrm{A}$ & $\begin{array}{c}\text { YILLIK } \\
\text { Toplam }\end{array}$ \\
\hline Boyabat & 32 & 20.3 & 14.0 & 8.5 & 1.4 & 0.0 & - & - & - & - & 0.5 & 7.3 & 13.8 & 65,8 \\
\hline Kastamonu & 40 & 25.3 & 21.6 & 16.7 & 4.2 & 0.6 & - & - & - & - & 2.1 & 12.7 & 21.8 & 105 \\
\hline Sinop & 40 & 1.8 & 2.4 & 0.6 & - & - & - & - & - & - & - & 0.0 & 0.2 & 5 \\
\hline
\end{tabular}

Tablo 2'ye göre inceleme sahasının yıllık ortalama donlu gün sayısının 65,8 gün olduğu görülmektedir. Bu değerler Kastamonu'da 105 gün iken, Sinop'ta 5 gün ile sınırlı kalmıştır. 


\subsection{Basınç ve Rüzgar Durumu}

Sıcaklık, yükselti ve enleme bağlı olarak değişen hava basıncı; sıcaklık, nemlilik, yağış ve rüzgâr gibi iklim elemanlarına etkileri açısından büyük önem taşımaktadır. Tablo 3'e göre Boyabat'ın basınç değerleri aşağıdaki gibidir.

Tablo 3. Boyabat'ın ortalama en yüksek ve ortalama en düşük yerel basınç değerleri

\begin{tabular}{cccccccccccccc}
\hline Değerler & $\mathrm{O}$ & $\mathrm{S}$ & $\mathrm{M}$ & $\mathrm{N}$ & $\mathrm{M}$ & $\mathrm{H}$ & $\mathrm{T}$ & $\mathrm{A}$ & $\mathrm{Ey}$ & $\mathrm{E}$ & $\mathrm{K}$ & $\mathrm{A}$ & Ort. \\
\hline $\begin{array}{c}\text { Ortalama } \\
\text { Basıç(hPa) }\end{array}$ & 978 & 976 & 975 & 974 & 973 & 973 & 971 & 972 & 975 & 978 & 980 & 979 & 975 \\
\hline $\begin{array}{c}\text { Maksimum } \\
\text { Basıçc(hPa) }\end{array}$ & 997 & 993 & 992 & 986 & 982 & 982 & 979 & 979 & 985 & 989 & 991 & 997 & 997 \\
\hline $\begin{array}{c}\text { Minimum } \\
\text { Basıç(hPa) }\end{array}$ & 959 & 961 & 958 & 960 & 946 & 948 & 962 & 963 & 961 & 962 & 966 & 958 & 946. \\
\hline
\end{tabular}

Yörenin 8 yıllık rasat verilerine göre yıllık ortalama basınç değeri $975 \mathrm{hPa}$ 'dır. Maksimum basınç değeri $997 \mathrm{hPa}$, minimum basınç değeri 946 hPa'dır. Tablo 4 'te Boyabat'taki rüzgar esme sayıları şu şekildedir.

Tablo 4. Boyabat'ta aylık ve yıllık toplam rüzgar esme sayıları ve yönleri

\begin{tabular}{ccccccccccccccc}
\hline Boyabat & $\begin{array}{c}\text { Rasat } \\
\text { Y1li }\end{array}$ & $\mathrm{O}$ & $\mathrm{S}$ & $\mathrm{M}$ & $\mathrm{N}$ & $\mathrm{M}$ & $\mathrm{H}$ & $\mathrm{T}$ & $\mathrm{A}$ & $\mathrm{E}$ & $\mathrm{Ek}$ & $\mathrm{K}$ & A & Y1llik \\
\hline $\mathrm{N}$ & 32 & 1438 & 1535 & 1840 & 1825 & 1748 & 1877 & 2082 & 2239 & 1884 & 1566 & 1439 & 1305 & 20778 \\
\hline $\mathrm{NE}$ & 32 & 821 & 883 & 1315 & 1377 & 1804 & 1474 & 1772 & 1706 & 1377 & 1228 & 678 & 573 & 15008 \\
\hline $\mathrm{E}$ & 32 & 966 & 1146 & 1573 & 1418 & 1431 & 1322 & 1513 & 1434 & 1285 & 1094 & 908 & 922 & 15012 \\
\hline $\mathrm{SE}$ & 32 & 1243 & 1329 & 1744 & 1869 & 1654 & 1310 & 1401 & 1284 & 1152 & 1440 & 1088 & 1006 & 16520 \\
\hline $\mathrm{S}$ & 32 & 1015 & 1073 & 1101 & 1183 & 1200 & 1067 & 1195 & 1118 & 989 & 1193 & 849 & 667 & 12650 \\
\hline SW & 32 & 850 & 738 & 1049 & 1088 & 793 & 768 & 610 & 724 & 630 & 789 & 783 & 660 & 9482 \\
\hline $\mathrm{W}$ & 32 & 2817 & 2632 & 2622 & 2272 & 2519 & 2190 & 2036 & 2201 & 2520 & 2680 & 2429 & 2810 & 29728 \\
\hline $\mathrm{NW}$ & 32 & 1669 & 1548 & 1650 & 1359 & 1170 & 1200 & 1274 & 1385 & 1501 & 1263 & 1294 & 1468 & 16781 \\
\hline
\end{tabular}

Boyabat'ta tablo 4'e göre rüzgarın esiş yönü ve esme sayıları dikkate alındığında rüzgarın en fazla batı ve kuzey yönlerden estiği görülmektedir. En az esme sayısı ise güneydoğu yönündendir. Boyabat'ta Rubinstein formülüne göre; yıllık hâkim rüzgar yönü N'den $67^{\circ} \mathrm{W}$ istikametindedir. Rüzgârın bu yöndeki frekansı \% 35 oranındadır. İlkbahar hakim rüzgar yönü $\mathrm{N}^{\prime}$ den $75^{\circ} \mathrm{W}, \mathrm{N}^{\prime}$ den $15^{\circ} \mathrm{E}$ ve S'den $72^{\circ} \mathrm{E}$; yaz mevsimde $\mathrm{N}^{\prime}$ den $15^{\circ} \mathrm{E}$; sonbaharda $\mathrm{N}^{\prime}$ den $72^{\circ}$ $\mathrm{W}$ ve kış mevsiminde $\mathrm{N}$ 'den $72^{\circ} \mathrm{W}$ istikametindedir. Şekil 3 Boyabat'ın yıllık ortalama rüzgar frekans gülünü göstermektedir.

Şekil 3. Boyabat'in y1llık ortalama rüzgâr frekans gülü

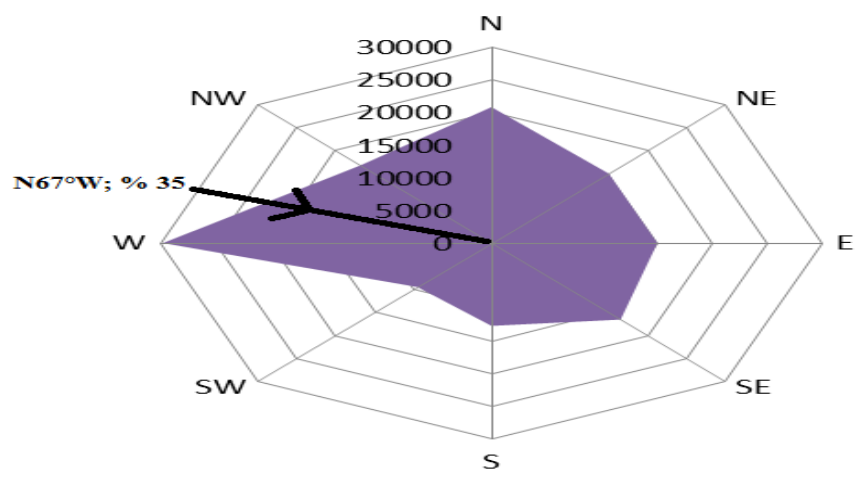

Boyabat'ta yıllık ortalama rüzgar frekans gülü incelendiğinde sahada yıl boyunca batı sektörlü rüzgarların etkili olduğu görülmektedir. Boyabat'ta $\mathrm{W}$ sektörlü rüzgarlardan sonra en fazla N ve NW sektörlü rüzgarlar etkili olmaktadır (Şekil 3). Yine sahada daha sonra N ve NW sektörlü rüzgarlar etkili olmaktadır. Şekil 4'te Boyabat'ın mevsimlere göre rüzgar gülü grafikleri gösterilmiştir. 
Şekil 4. Boyabat'in mevsimlere göre ortalama rüzgâr frekans gülü
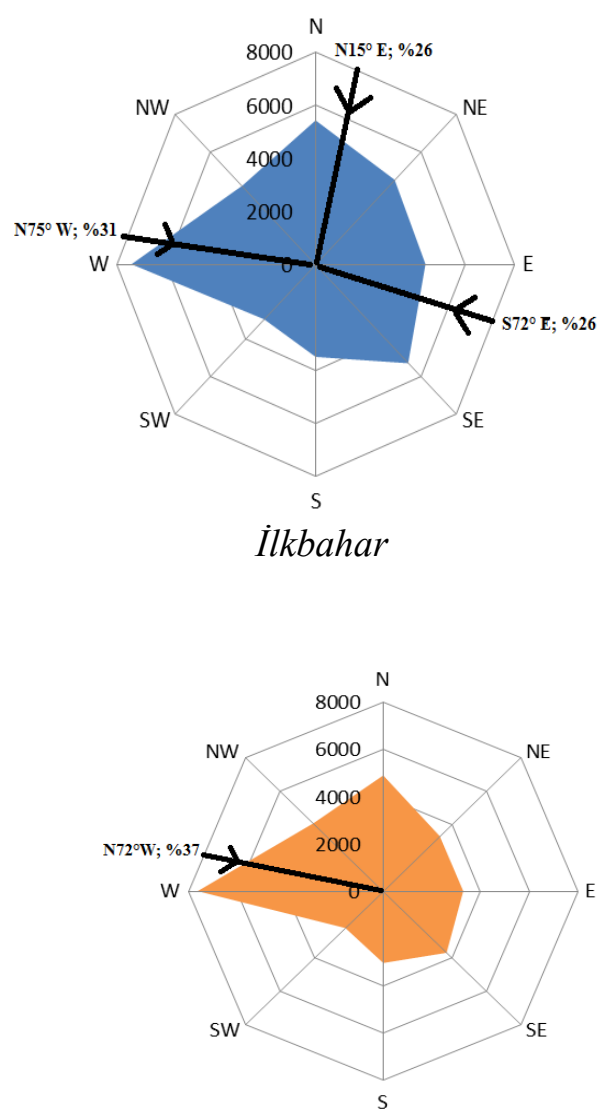

Sonbahar
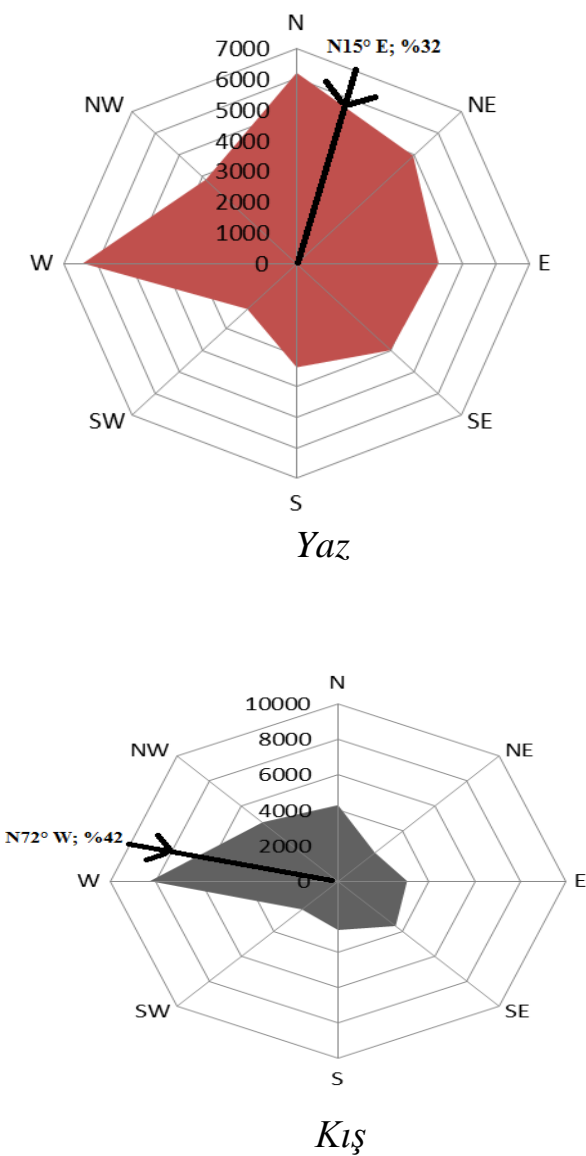

Şekil 4'e göre Boyabat'ta sonbahar ve kış mevsiminde batı sektörlü rüzgarların hakim olduğu; yaz mevsiminde ise hakim rüzgar yönün $\mathrm{N}$; ilkbahar mevsiminde ise $\mathrm{W}, \mathrm{N}$ ve $\mathrm{SE}$ olmak üzere üç farklı hakim rüzgar yönünün olduğu görülmektedir. Boyabat'ta mevsimlere göre rüzgar hız ve yönleri tablo 5'te gösterilmiştir.

Tablo 5. Boyabat'ta mevsimlere göre ortalama rüzgar hızları ve yönleri $(\mathrm{m} / \mathrm{sn})$

\begin{tabular}{ccccc}
\hline Yönler & Kiş & İkbahar & Yaz & Sonbahar \\
\hline $\mathrm{N}$ & 1,2 & 1,5 & 1,8 & 1,3 \\
\hline $\mathrm{NE}$ & 1,2 & 1,7 & 1,9 & 1,4 \\
\hline $\mathrm{E}$ & 1,2 & 1,4 & 1,4 & 1,2 \\
\hline $\mathrm{SE}$ & 1,2 & 1,4 & 1,4 & 1,2 \\
\hline $\mathrm{S}$ & 1,1 & 1,4 & 1,3 & 1,2 \\
\hline $\mathrm{SW}$ & 1,1 & 1,5 & 1,5 & 1,2 \\
\hline $\mathrm{W}$ & 1,3 & 1,5 & 1,5 & 1,4 \\
\hline $\mathrm{NW}$ & 1,4 & 1,6 & 1,6 & 1,4 \\
\hline
\end{tabular}

Rüzgârların esme yönü ile birlikte esme hızları da iklim özellikleri ile fiziki ve beşeri çevreye etkileri bağlamında değerli verilerdir. Tablo 5 incelediğinde Boyabat'ta rüzgar hızı en fazla $(1,9 \mathrm{~m} / \mathrm{sn})$ yaz mevsimindedir. En düşük rüzgar hızı ise $(1.1 \mathrm{~m} / \mathrm{sn}) \mathrm{k}$ ş̧ mevsiminde görülmektedir. Fırtınalı gün sayısı en fazla yaz aylarında (0.1gün) görülmektedir.

\subsection{Nemlilik ve Yağış}

Havada bulunan bağıl nem oranı havanın yağış ihtimalini ifade etmektedir. Bağıl nem oranı su buharı ve sıcaklık şartlarına göre değişmektedir. Boyabat'ın bağıl nem ve bulutluluk oranları tablo 6'da gösterilmiştir. 
Tablo 6. Boyabat'ın ortalama bağıl nem ve bulutluluk oranı değerleri

\begin{tabular}{ccccccccccccccc}
\hline Aylar & $\mathrm{O}$ & $\mathrm{S}$ & $\mathrm{M}$ & $\mathrm{N}$ & $\mathrm{M}$ & $\mathrm{H}$ & $\mathrm{T}$ & $\mathrm{A}$ & $\mathrm{E}$ & $\mathrm{Ek}$ & $\mathrm{K}$ & $\mathrm{A}$ & $\begin{array}{c}\text { Y1llk } \\
\text { Ort. }\end{array}$ \\
\hline $\begin{array}{c}\text { Ortalama } \\
\text { Bağ1l } \\
\text { Nem(\%) }\end{array}$ & 72.5 & 65.9 & 60.3 & 58.6 & 57.8 & 54.3 & 49.8 & 50.0 & 53.3 & 62.2 & 70.4 & 74.4 & 60.8 \\
\hline $\begin{array}{c}\text { Ortalama } \\
\text { Bulutluluk }\end{array}$ & 7.0 & 6.2 & 5.7 & 5.8 & 5.1 & 3.9 & 3.1 & 2.8 & 3.7 & 5.1 & 6.2 & 7.1 & 5.1 \\
\hline
\end{tabular}

Boyabat'ta yıllık ortalama bağıl nem \% 60,8'dir. Mart- ekim ayları arasında bağıl nem oranı yıllık ortalamanın altındadır. En yüksek bağıl nem aralık ayında görülmektedir. Kastamonu'da yıllık ortalama bağıl nem \% 68,5 iken Sinop'ta \% 74.9'dur. Bulutluluk oran1, gökyüzünün bulutlarla örtülü olma oranını göstermektedir. 0-10 arasında ifade edilen bulutluluk oranı, havanın açık, parçalı bulutlu veya kapalı olma durumu hakkında bilgi vermektedir. Boyabat'ın ortalama bulutluluk (0-10) oranı 5.1'dir. Haziran ile eylül ayları arasında bulutluluk oranı ortalama değerinin altındadır. Bağıl nem oranında olduğu gibi bulutluluk oranı da en fazla aralık ayında gerçekleşmektedir. Kastamonu'da yıllık ortalama bulutluluk oranı Boyabat'taki gibi 5.1, Sinop'ta ise 5.4'tür. Şekil 5'te Boyabat'ın yıllık ortalama yağış dağıllış1 gösterilmektedir.

Şekil 5. Boyabat'ta yıllık ortalama yağışın aylara dağılışı

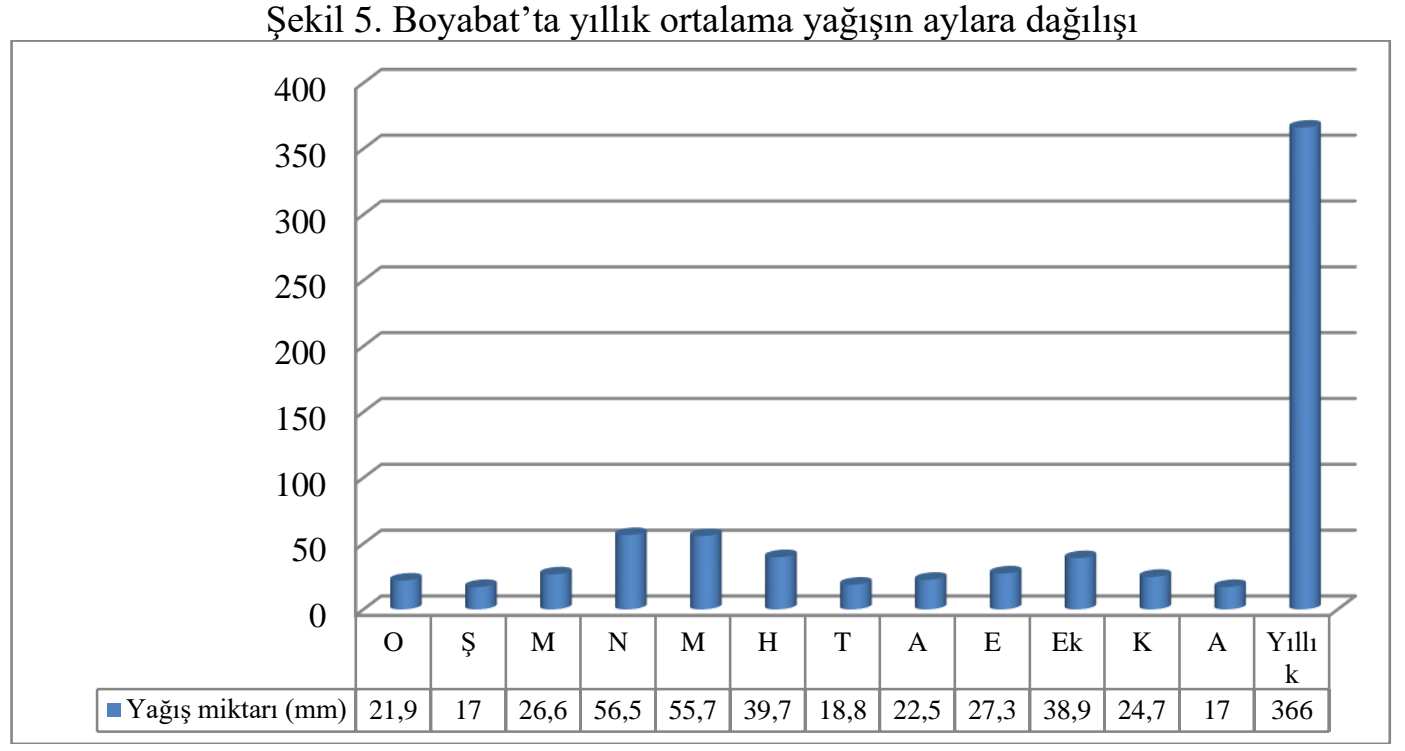

32 yıllık rasatlara göre Boyabat'a yıllık ortalama 366 mm yağış düşmektedir. Yağış miktarının en az olduğu aylar $17 \mathrm{~mm}$ ile şubat ve aralık aylarıdır. Yıl içinde en fazla yağışın düştügü ay $56,5 \mathrm{~mm}$ ile nisan olmuştur. Kastamonu'da yıllık ortalama yağış $505 \mathrm{~mm}$ iken, Sinop'ta 690 mm'dir. Şekil 6 Boyabat'ta yağışın mevsimlere göre dağılımını göstermektedir.

Şekil 6. Yıllık ortalama yağışın mevsimlere dağılışı.

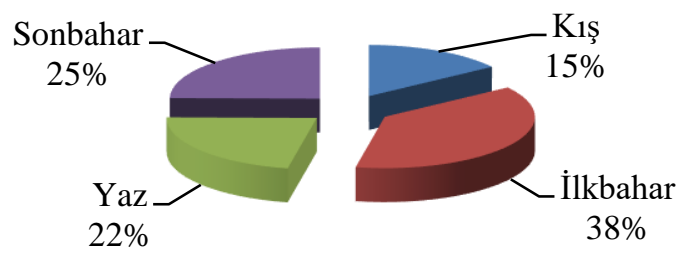


Yörede yağışın mevsimlere göre dağılımında yağış en fazla ilkbaharda, en az yağış ise \% 15'lik oran ile kış mevsiminde düşmektedir. Boyabat'taki gibi Kastamonu'da da en fazla yağış ilkbaharda, Sinop'ta ise en fazla yağış sonbaharda düşmektedir. Şekil 7'de Boyabat'in muhtemel yağış dağılışı gösterilmektedir.

Şekil 7. Boyabat'ın muhtemel yağış dağılışı

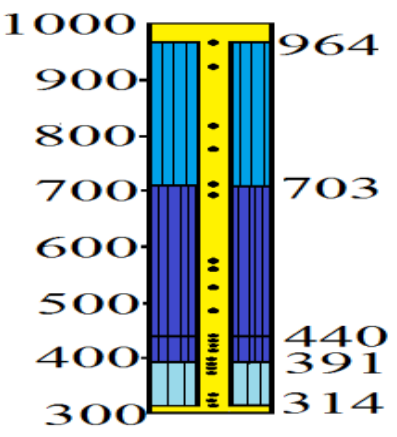

Yörenin muhtemel yağış değerlerine göre oluşturulmuş grafik aşağıdaki gibidir. 32 yıllık rasatlara göre Boyabat'ta yağışın \%25' i 314- 391 mm arasında, \% 50'si 391-440 mm arasında ve \% 25'i 703-964 mm arasında düşmüştür. Var olan ölçümler göstermektedir ki bu yörede yağışların 314 mm'den az ve 964 mm'den fazla olma ihtimali bulunmamaktadır. Şekil 8 Boyabat'ın klimogramını göstermektedir.

Şekil 8. Boyabat klimogramı

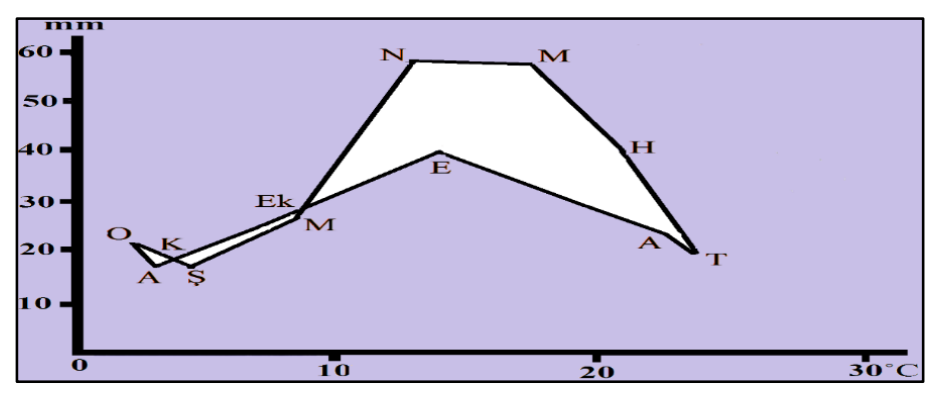

Klimogramlar iklim diyagramlarının başka bir şeklidir. Klimogramların çizilmesi için yatay eksen üzerine sıcaklık değerleri, dikey eksen üzerinde ise yağış değerleri işaretlenir. Her aya ait sıcaklık ve yağış değerleri bu şekil üzerinde kesiştirilerek noktalar birleştirildiğinde kapalı bir şekil elde edilir. Her ayın sıcaklık ve yağış değerlerini birleştirerek elde edilen şekil, o yerin iklim karakterini gösterir. Ortaya çıkan kapalı şekil yuvarlak ise, bu sıcaklık ve yağış bakımından mevsimler arasında çok fark bulunmayan iklim tipini; ortaya çıkan kapalı şekil uzun ise bu da yağış ve sıcaklık bakımından mevsimler arasında çok fark olan iklim tipini yansıtır (KŞM, 2014).

Şekil 8'de Boyabat için oluşturulan klimogramda ortaya çıkan şekil ne yuvarlak, ne de ince uzun bir şekil olup, her ikisini de temsil eden bir şekil ortaya çıkmıştır. Klimogramda, sonbahar ve kış ayları benzerlik gösterirken, ilkbahar ve yaz ayları birbirinden oldukça farklı görülmektedir. Boyabat'ta su bilançosundaki değişim Tablo 7 ile Şekil 9'da gösterilmiştir. İlçede topraktaki su birikimi kasım ayında başlamaktadır. Bu durumun Aralık, Ocak ve Şubat ayları boyunca devam eder. Mart ayında topraktaki su birikimi az bir miktar azalsa bile nisan ayında tekrar artar. Nisan ayından itibaren su fazlalığı olmadan topraktaki su birikimi azalır ve haziranekim dönemi boyunca toprakta su eksikliği söz konusudur. Aydınözü (2002) çalışmasında Kastamonu ve Sinop'un su bilançosunu incelemiştir. Buna göre Boyabat'ta hiçbir ayda olmayan toprağın suya doygunluğu Kastamonu'da 3 ay, Sinop'ta 4 ay yaşanmaktadır. Yine aynı şekilde Boyabat'ta su fazlalığı yok iken Kastamonu'da $21 \mathrm{~mm}$, Sinop'ta $156.5 \mathrm{~mm}$ su fazlalığ bulunmaktadır. 
Tablo 7. Thornthwaite formülüne göre Boyabat'in su bilançosu tablosu

\begin{tabular}{|c|c|c|c|c|c|c|c|c|c|c|c|c|c|}
\hline Aylar & $\mathrm{O}$ & Ş & $\mathrm{M}$ & $\mathrm{N}$ & $\mathrm{M}$ & $\mathrm{H}$ & $\mathrm{T}$ & A & $\mathrm{E}$ & Ek & $\mathrm{K}$ & A & Yillık \\
\hline Sicaklık & 2,4 & 4,5 & 8,2 & 12,9 & 17,4 & 21,1 & 23,7 & 23,5 & 19,6 & 14,0 & 7,5 & 3,8 & 13,2 \\
\hline Sicaklık İndisi & 0,31 & 0,85 & 2,12 & 4,20 & 6,61 & 8,85 & $\begin{array}{c}10,5 \\
5\end{array}$ & 10,4 & 7,91 & 4,75 & 1,85 & 0,6 & 59,07 \\
\hline $\begin{array}{l}\text { Düzeltilmemiş } \\
\text { PE }\end{array}$ & 4,5 & 11 & 28 & 49 & 74 & 96 & 112 & 110 & 86 & 55 & 24 & 9 & \\
\hline Düzeltilmiș PE & 4 & 9 & 29 & 54 & 93 & 121 & 142 & 131 & 89 & 53 & 20 & 7 & 752 \\
\hline Yağış̧ & 21,9 & 17 & 26,6 & 56,5 & 55,7 & 39,7 & 18,8 & 22,5 & 27,3 & 38,9 & 24,7 & 17 & 366,6 \\
\hline $\begin{array}{l}\text { Birikmiş Suyun } \\
\text { Aylık Değişimi }\end{array}$ & 17,9 & 8 & $-2,4$ & 2,5 & $\begin{array}{l}- \\
37,3\end{array}$ & $-3,4$ & 0 & 0 & 0 & 0 & 4,7 & 10 & \\
\hline Birikmiş Su & 32,6 & 40,6 & 38,2 & 40,7 & 3,4 & 0 & 0 & 0 & 0 & 0 & 4,7 & 14,7 & 0 \\
\hline Gerçek Eva. & 4 & 9 & 29 & 54 & 93 & 43,1 & 18,8 & 22,5 & 27,3 & 38,9 & 20 & 7 & 366,6 \\
\hline Su Noksan1 & 0 & 0 & 0 & 0 & 0 & 77,9 & $\begin{array}{c}123, \\
2\end{array}$ & $\begin{array}{c}108, \\
5\end{array}$ & 61,7 & 14,1 & 0 & 0 & 385,4 \\
\hline Su Fazlas1 & 0 & 0 & 0 & 0 & 0 & 0 & 0 & 0 & 0 & 0 & 0 & 0 & 0 \\
\hline
\end{tabular}

Şekil 9. Boyabat'ın su bilançosu grafiği (Thornthwaite metoduna göre)

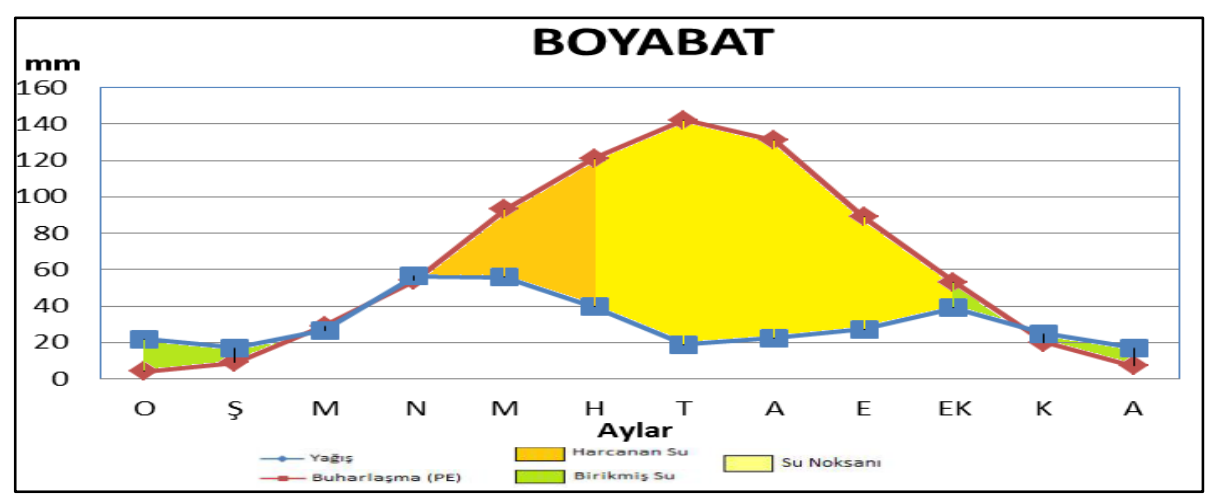

İnceleme alanının Thornthwaite yöntemiyle değerlendirilmesi ile elde edilen sonuçlara göre Boyabat'1n iklim tipi DB'2db'3 harfleri ile ifade edilen, yarı kurak, ikinci dereceden mezotermal, su fazlası olmayan yahut pek az olan ve deniz tesirli iklim tipi olarak tanımlanmaktadır. Meteoroloji Genel Müdürlüğü verilerine göre Kastamonu $\mathrm{C}_{1} \mathrm{~B}_{1}$ 'db'3 yani kurak-az nemli, birinci dereceden mezotermal, su fazlası olmayan yahut pek az olan iklim tipinde iken, Sinop C1,B'2sb'4 yani yarı kurak-az nemli, ikinci derecen mezotermal, su fazlası kış mevsiminde ve orta derecede olan denizel iklim tipine girmektedir.

De Martonne yöntemine ${ }^{3}$ göre Boyabat'ın iklimi tasnif edildiğinde; $[366 /(13.2+10)+$ $(12 * 17 /(3,8+10)] / 2=15.2$ çıkmaktadır.

Tablo 8. De Martonne yöntemine göre iklim grupları

\begin{tabular}{ll}
\hline İklim Tipi & Kuraklık İndeksi \\
\hline Çöl & $0-5$ \\
\hline Step (Yarı Kurak) & $5-10$ \\
\hline Step-Nemli arası & $10-20$ \\
\hline Yarı Nemli & $20-28$ \\
\hline Nemli & $28-35$ \\
\hline Çok Nemli & $35-55$ \\
\hline Islak & $>55$ \\
\hline Kutupsal & $<0(\mathrm{~T}<-5 \mathrm{oC})$ \\
\hline
\end{tabular}

Kaynak: MGM

\footnotetext{
${ }^{3} \mathrm{Ia}=(\mathrm{P} /(\mathrm{T}+10)+(12 * \mathrm{p} /(\mathrm{t}+10))) / 2 ;$

$10=$ Sıcaklığın $0^{\circ} \mathrm{C}$ 'nin altında olduğu yerlerde t'yi pozitif yapmaya yarayan sabit sayı

$\mathrm{P}=$ Uzun yıllar toplam yağıș $(\mathrm{mm})$;

$\mathrm{T}=$ Uzun yıllar ortalama hava sicaklığ $1\left({ }^{\circ} \mathrm{C}\right)$.

$\mathrm{p}=$ En kurak ayın yağışı $(\mathrm{mm})$;

$\mathrm{t}=$ En kurak ayın ortalama sicaklığ $1\left({ }^{\circ} \mathrm{C}\right)$
} 
Bu sonuca göre Boyabat step- nemli iklim özelliğine sahiptir. MGM verilerine göre Sinop ve Kastamonu da De Martonne yöntemine göre step-nemli iklim grubundadır.

Erinç yöntemine göre ${ }^{4}$ Boyabat'ın iklimi tasnif edildiğinde;

$\mathrm{Im}=366 / 19,8=18.5$ sonucu elde edilmektedir.

Tablo 9. Erinç yöntemine göre iklim grupları

\begin{tabular}{llll}
\hline İklim Sınıfı & İndis Değeri(Im) & \multicolumn{2}{c}{ Bitki Örtüsü } \\
\hline Tam Kurak & $<8$ & Çöl \\
\hline Kurak & $8-15$ & Çöl-Step & \\
\hline Yarı Kurak & $15-23$ & Step & \\
\hline Yarı Nemli & $23-40$ & Park görünümlü kuru & orman \\
\hline Nemli & $40-55$ & Nemli orman & \\
\hline Çok Nemli & $>55$ & Çok nemli orman & \\
\hline \multicolumn{5}{c}{ Kaynak: MGM } &
\end{tabular}

Bu sonuca göre Boyabat yarı kurak iklim sınıfında yer alıp, step bitki örtüsüne sahiptir. MGM verilerine göre Sinop ve Kastamonu yarı nemli iklim sinıfında yer almaktadır. Ancak Aydeniz'e göre ise Boyabat ve çevresi yarı nemli iklimler grubunda değerlendirilmektedir (Şekil $10)$.

Şekil 10. Aydeniz'e göre Türkiye iklimi (Klimatoloji Şube, 2016)

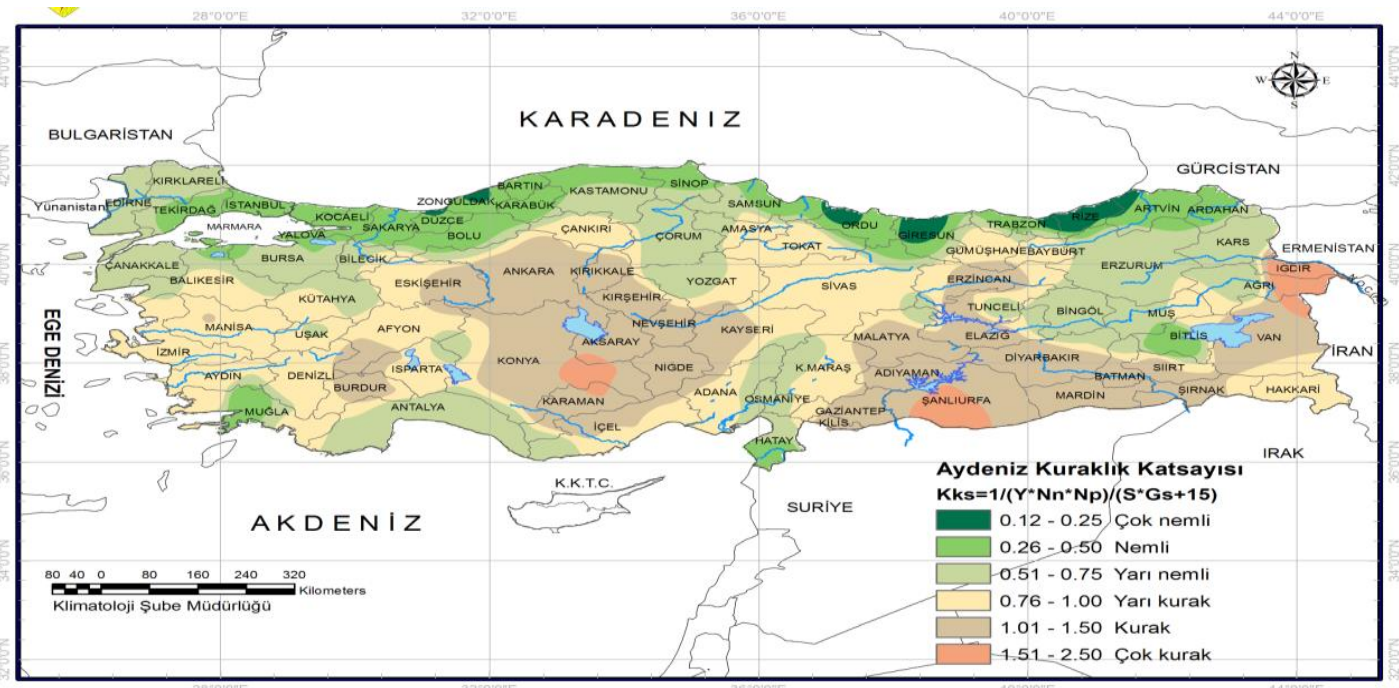

\section{Sonuç ve Öneriler}

Bir yerin iklim tipini tespit edebilmek için öncelikle sıcaklık, basınç ve rüzgar, nem ve yağış gibi iklim elemanlarına ait özelliklerinin tespit edilmesi gerekmektedir. Bu nedenle Boyabat ilçesinin iklim özelliklerini tespit etmeyi amaçladığımız bu çalışmada iklim elemanlarına ait veriler değerlendirilmiştir. Bu çalışmayı yaparken kıyaslama amacıyla bir tane kıyıdan bir tane de iç kesimden olmak üzere iki ilin verilerinden yararlanılmıştır. Sıcaklık ve yağış değerlerinden elde edilen sonuçlara göre Boyabat çevresindeki hem diğer karasal ortamlara (Kastamonu ($\left.1,2^{\circ} \mathrm{C}\right)$, Çorum $\left(-0,7^{\circ} \mathrm{C}\right)$, Bolu $\left(0,5^{\circ} \mathrm{C}\right)$, Çankırı $\left(-1^{\circ} \mathrm{C}\right)$ göre hem de ülkemizin iç kesimlerinde yer alan illere göre kışları çok daha 1lık geçen bir iklime sahiptir.

Yaz mevsiminde de çevresindeki hem sahil hem de iç kesim illerine (Kastamonu $\left(20^{\circ} \mathrm{C}\right)$, Çorum $\left(20,6^{\circ} \mathrm{C}\right)$, Bolu $\left(19,5^{\circ} \mathrm{C}\right)$, Sinop $\left(22,5^{\circ} \mathrm{C}\right)$, Samsun $\left(23^{\circ} \mathrm{C}\right)$ göre daha fazla 1sınmaktadır.

\footnotetext{
${ }^{4} \mathrm{Im}=\mathrm{P} / \mathrm{T}_{\mathrm{om}} \mathrm{P}=$ yıllık toplam yağ ${ }_{1 S ̧}(\mathrm{~mm})$, Tom = yıllık ortalama maksimum sıcaklık. (Erinç, S., 1984)
} 
Araştırma sahasının yağış özellikleri incelendiğinde yağış miktarının az olduğu bir iklime tipine sahip olduğu sonucu ortaya çıkmıştır. Meteoroloji verilerine göre ülkemizde ortalama yağış miktarı 574 mm iken Boyabat'ta ortalama yağış miktarı 366 mm'dir.

Bunun nedeni, Küre dağlarının denizden gelen hava kütlelerine açık kuzey yamaçlarına yağı̧̧ı bıraktırması ve kuru hava kütlelerinin Boyabat depresyonunun yakın çevrelerine bakan güney yamaçlarına yeterince yağış bırakamamasından kaynaklanmaktadır. Ayrıca inceleme sahasında yükseltinin az olması nedeniyle yağış genellikle $500 \mathrm{~mm}$. yi bulmaz. Gökırmak vadisinde doğudan batıya doğru gidildikçe hem yükselti hem de yağış miktarı birazcık artar. Doğuda Gökırmak vadisinde deniz seviyesinden 350m. yükseltide bulunan Boyabat $366 \mathrm{~mm}$. yağış alır.

Boyabat'ın bu sıcaklık ve yağış değerleri ile farklı iklim sınıflandırma sistemlerine göre değerlendirmesi yapılmıştır. Boyabat Thornthwaite yöntemine göre yarı kurak, ikinci dereceden mezotermal, su fazlası olmayan yahut pek az olan ve deniz tesirli iklim tipine; De Martonne yöntemine göre step- nemli iklim tipine; Erinç yöntemine göre yarı kurak iklim tipine; Aydeniz yöntemine göre yarı nemli iklim tipine sahiptir. Bu dört yöntemin ortaya çıkardığı ortak sonuca göre genel anlamda Boyabat kışları serin, yazları sıcak geçen ve az yağış alan bir iklim özelliğine sahiptir.

Bir yerin iklim özellikleri ve sınırlarının tespiti ve tatbiki o yörede yapılacak beşeri ve ekonomik faaliyetlerde en üst düzeyde verim alınmasını sağlayacaktır. Bu görüş çerçevesinde yöreye ait birtakım öneriler getirilebilir;

Thornthwaite yöntemine göre hazırlanan su bilançosu yörede toprağın suya doygun bir dönemin olmadığını göstermektedir. Bu da yörenin içme suyu ihtiyacında var olan sıkıntıları dönem dönem artırmaktadır. Bu yüzden yörede içme suyu temini için alternatif yolların bulunması gerekmektedir.

Doğu-batı doğrultulu bir ovaya sahip olan ilçede en fazla üretilen tarım ürünü pirinçtir. Gelenekselleşen çeltik tarımı nedeniyle yörede tarımsal anlamda su ihtiyacı had safhaya ulaşmaktadır. Bu yüzden pirinç tarımının ekim alanlarının daraltılıp yerine daha fazla gelir getiren tarım ürünleri yetiştirilebilir. Yöredeki yaz sıcaklık ortalamasının yüksek olduğu göz önüne alınarak alternatif tarım ürünleri ziraat müdürlükleri öncülüğünde belirlenmesi iyi bir ek gelir kaynağı olabilir.

Yörede kışların ılık geçmesi, kızılçam ağaçlarının geniş yer tutması ve bazı maki türlerinin varlığı Akdeniz iklimini anımsatmaktadır. Ayrıca yörede toprak sıcaklık değerleri de yüksektir. $\mathrm{Bu}$ şartlar değerlendirilerek ziraat odası ve ziraat mühendislerinin katkılarıyla geleneksel olarak yetiştirilen tarım ürünlerine alternatif ürünler denenebilir.

Yıllık yağış miktarının Türkiye ortalamasının çok altında olduğu yörede yarı kurak iklim şartları hüküm sürmektedir. Tarımın iklime olan bağlılığını azaltmak adına çiftçilere modern sulama sistemlerinin kullanımı teşvik edilmelidir. Böylece hem doğal su kaynakları bilinçsizce tüketilmemiş olacaktır hem de daha fazla tarım alanı sulanabilir hale gelecektir.

Depresyon (çukur) alanında bulunan ilçede kirli havayı taşıyacak kadar yeterli rüzgar olmadığından özellikle kışın hava kirliliği ısınma amaçlı kömür kullanımı nedeniyle artmaktadır. Bu yüzden en kısa süre içerisinde ilçede doğalgaz kullanımının başlanması gerekmektedir.

\section{Kaynakça}

Aksever, F. ve Eroğlu, A. (2016). Çivril-Baklan (Denizli) Ovasında Yeraltı suyuna İklim Değişikliğinin Etkisi. Mehmet Akif Ersoy Üniversitesi Fen Bilimleri Enstitüsü Dergisi, 7(1), 11-26.

Ardel, A., Kurter, A., Dönmez, Y. (1969). Klimatoloji Tatbikatı, İstanbul Üniversitesi Yayınları No: 1 123, İstanbul. 
Aydınözü, D. (2002). Küre Dağları Doğu Kesiminin Bitki Coğrafyası (Yayınlanmamış doktora tezi). İstanbul Üniversitesi Sosyal Bilimler Enstitüsü, İstanbul.

Aydınözü,D., İbret,B.Ü., İmat,F. (2012). Jeolojik miras açısından değerlendirilmesi gereken bir yöremiz: Boyabat Sultansuyu Bazalt Sütunlart, Atatürk Üniversitesi, Edebiyat Fakültesi, Coğrafya Bölümü, I. Ulusal Coğrafya Sempozyumu, Bildiriler Kitabı 28-30 Mayıs 2012, Erzurum.

Çoban, A. (2013). Sungurlu-Boğazkale yöresinin iklim tipleri ve bazı öneriler. International Journal of Social Science, 6(3), 149-158.

DMİ. (1972). Türkiye İklim Tasnifi (De Martonne Metoduna Göre). Ankara

DMİ. (1988). Aydeniz Metodu ile Türkiye’nin Kuraklık Değerlendirmesi, Ankara.

Erinç, S. (1984). Klimatoloji ve Metotları, İ.T.Ü. Deniz Bilimleri ve Coğrafya Enstitüsü, İstanbul.

EROL, O. (1993).Genel Klimatoloji, Ankara: Gazi Büro Kitabevi.

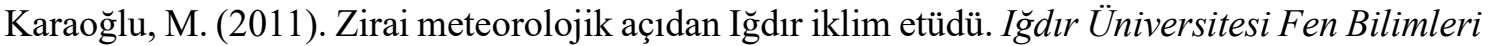
Enstitüsü Dergisi, 1(1).

KŞM (2016). Aydeniz iklim sinıflandırmasına göre Türkiye iklimi. https://www.mgm.gov.tr/FILES/iklim/iklim_siniflandirmalari/aydeniz.pdf Erişim Tarihi: 15.02.2020.

MGM (2019). Thornthwaite iklim sinıflandırmasına göre Türkiye iklimi. https://www.mgm.gov.tr/FILES/iklim/iklim_siniflandirmalari/Thornthwaite.pdf. Erişim Tarihi: 15.03 .2020

Öztürk, M. Z., Çetinkaya, G., Aydın, S. (2017). Köppen-Geiger iklim sınıflandırmasına göre $\begin{array}{lllll}\text { Türkiye'nin iklim tipleri. Cografya Dergisi, } & 35, & \text { 17-27. }\end{array}$ https://doi.org/10.26650/JGEOG330955.

Sağdıç, M. ve Koç, H. (2012). Yukarı Kızılırmak Havzası'nın iklimi. Türk Coğrafya Dergisi, (58).

Sarıcı, G. (2015). Araç ilçesinin fiziki coğrafya özellikleri (Yayınlanmamış yüksek lisans tezi). Sakarya Üniversitesi Sosyal Bilimler Enstitüsü, Sakarya.

Y1lmaz, F. ve Y1lmaz, Ö. (2013). Thornthwaite iklim tasnifine göre Rize ve Ardahan Örnekleri, 3rd International Geography Symposium - GEOMED 2013.

\section{ETİK ve BİLIMSEL İLKELER SORUMLULUK BEYANI}

$\mathrm{Bu}$ çalışmanın tüm hazırlanma süreçlerinde etik kurallara ve bilimsel atıf gösterme ilkelerine riayet edildiğini yazar(lar) beyan eder. Aksi bir durumun tespiti halinde Afyon Kocatepe Üniversitesi Sosyal Bilimler Dergisi'nin hiçbir sorumluluğu olmayıp, tüm sorumluluk makale yazarlarına aittir. 